\title{
A strategic reset: micro-credentials for higher education leaders
}

\author{
Rory McGreal ${ }^{1 *}$ (1) and Don Olcott Jr. ${ }^{2}$
}

\section{${ }^{*}$ Correspondence:}

rory@athabascau.ca

${ }^{1}$ Athabasca University,

Alberta, Canada

Full list of author information

is available at the end of the

article

\begin{abstract}
This article provides university leaders an introduction to the emerging micro-credentials field, including a snapshot of the global landscape. Despite the accelerated interest in micro-credentials, this article also raises a fundamental strategic question for leaders at the outset: Are micro-credentials right for our university? Part I discusses the basic elements of mcro-credentials, definitions, types of micro-credentials, and affordances and barriers and various providers of micro-credentials. Part II presents a snapshot of what is happening on the global playing field and the challenges inherent in trying to standardise micro-credentials globally. The final section of the article provides some general observations by the authors, lessons from practice, and brief example of how institutions may implement a strategic reset using micro-credentials. The authors close by emphasising micro-credentials are not a panacea for resolving institutional challenges and they are unlikely to become a major revenue enhancement. They may provide strategic value in their integration with other major institutional initiatives.
\end{abstract}

Keywords: Micro-credentials, Competencies, Strategy, Mission, Employers, Economic development, Alternative credentials, ADC

\section{Introduction}

The global workforce and economy are at a crossroads. Amidst the dramatic economic fallout of the COVID-19 pandemic, organisations in the public and private sector are increasingly faced with new economic and workforce imperatives for the future (Carnevale et al., 2020). Moreover, recent trends in the high cost of higher education, employer concerns about graduate skills and competencies, and student frustrations about the lack of job opportunities have all been catalysts for universities, independent credentialing agencies, and leaders of national qualification reference frameworks to rethink the broader credentials continuum (Bates, 2020; International Council for Open and Distance Education (ICDE), 2019; Matkin, 2018; Matkin, et al., 2020; Oliver, 2019; Selvaratnam, \& Sankey, 2020).

These economic shifts and a "credentials rethink" were already emerging, given employer demands for qualified workers along with students demanding more job opportunities, employment advancements, and mobility in their career paths (ICDE, 2019; Matkin et al., 2020). For example, in Canada, 38\% of employers have reported that they have been unable to hire the skilled workers that they need (CFIB, 2021). In

(c) The Author(s) 2022. Open Access This article is licensed under a Creative Commons Attribution 4.0 International License, which permits use, sharing, adaptation, distribution and reproduction in any medium or format, as long as you give appropriate credit to the original author(s) and the source, provide a link to the Creative Commons licence, and indicate if changes were made. The images or other third party material in this article are included in the article's Creative Commons licence, unless indicated otherwise in a credit line to the material. If material is not included in the article's Creative Commons licence and your intended use is not permitted by statutory regulation or exceeds the permitted use, you will need to obtain permission directly from the copyright holder. To view a copy of this licence, visit http:// creativecommons.org/licenses/by/4.0/. 
the USA also, there is a serious shortage, especially in computer-related fields (Envoy Global, 2021). A similar situation has been reported in Europe, where $40 \%$ of employers noted skill shortages (European MOOC Consortium, 2020). The boundaries of validated formal and nonformal learning are moving beyond the traditional credentials base of degrees and certificates, leading to an approach in which all relevant skill and competency learning can be validated, certified and transcripted not only by a university, but also by a third party as part of students' aggregated learning, skills, competencies, and experience (Contact Nord, 2020a, 2020b).

This shifting of practices towards unbundling higher education has resulted in an accelerated drive towards micro-credentials, sometimes referred to as alternative digital credentials (ADCs), nano degrees or badges (Deakin Co., 2017; ICDE, 2019; Selvaratnam, \& Sankey, 2020; Zanville, \& Ton-Quinlivan, 2020). According to one study, in mid2021, there are at least 1500 microcredentials, mainly based on MOOCs (Massive Open Online Courses). More than 75\% of the micro-credentials are in Business or Technology (Shah, 2021).

\section{Scope and Purpose: micro-credentials for university leaders}

The purpose of this article is to provide university leaders with guidance on micro-credentials to help institutional leaders assess their readiness and alignment to engage in the micro-credential market. The background data sets by the authors resulted from an extensive literature search, dialogues with various global institutional leaders, and their insights of nearly eighty years of practical engagement in distance learning, university outreach, cooperative extension, corporate training and management, and global leadership roles.

Indeed, there is a current tendency that seems to automatically assume all institutions will engage in this emerging market. The authors disagree with this view and argue that institutions must analyse and assess the landscape, including an inventory of their own institutional capacity to strategically reset their priorities to enter the market.

This article is designed to give the institutional leader an overview of the current landscape for micro-credentials which in turn may assist leaders in a strategic reset and decision to pursue this market. This article is not a prescriptive roadmap for institutional implementation of micro-credentials, rather it is a cautionary sign for leaders to ask this basic question whether to engage-go or no go. Strategic reset refers to institutions needing to reframe how they will implement micro-credentials if they pursue this market.

This article is divided into three main parts. Part I outlines key definitions, types of micro-credentials and their characteristics, issues of combining credit and noncredit credentials and affordances and barriers to micro-credentials.

Part II provides a snapshot of the global landscape with a focus on regions of extensive micro-credentials activity-Australia, U.S., Canada and Europe. It takes a consistent, systematic approach for the description and analysis of the contemporary status of micro-credentials, and related trends, for better comparison of the situations in different parts of the world, The authors attempt to delineate similarities and differencesd in approaches across regions recognising that a global standardisation of micro-credentials may be problematic for the short-term. 
The final section of this article concludes with a summary of key considerations for university leaders and some thoughts about the future by the authors. A selected list of micro-credential providers and agencies is provided in the appendix.

\section{Part I}

\section{Defining micro-credentials}

What are micro-credentials? Micro-credentials are certified documents that provide recognised proofs of the achievement of learning outcomes from shorter, less duration, educational or training activities. They focus on the validation of competency-based skills, outcomes and/or knowledge using transparent standards and reliable assessments, which can enhance graduates' employability prospects. A micro-credential can be be accepted for credit by an institution or organization or be an attestation for employers. A micro-credential attests to specific knowledge or skills competencies with defined learning outcomes and may or may not be stacked towards larger units of accreditation (Brown et al., 2021; Cirlan, \& Loukkola, 2020; COL, 2019; Debiais-Sainton, 2020; Fong et al., 2016; Kato et al., 2020).

The term Alternative Digital Credentials (ADCs) has also been used to define these credentials (ICDE \& OECD) by recognizing that not all micro-credentials are digital. They recognize the inherent usefulness of third-party transcripting services that can serve as repositories or portfolio homes for individuals and employers (Matkin, 2018; ICDE, 2019; Kato et al., 2020).

The micro-credentials landscape can be a means of accentuating assessment and validation processes. In different sectors, this could include credit and non-credit-bearing competency development. For the most part, micro-credentials exist outside the formal qualifications frameworks of traditional universities and colleges, yet these frameworks provide formal guidance, because learners will want micro-credentials to be transparent and applicable to formal credentials. They may or may not be stackable or combinable towards higher qualifications, and in some cases may be accepted into formal certificate and/or degree credit programmes (ICDE, 2019; Kato et al., 2020).

Appendix A provides a selected summary of global micro-credentials providers and the reader is encouraged to review those institutions that are similar to theirs to gain an initiail understanding of how institutional leaders are approaching this market. Brown et al. (2021) provides an abbreviated summary of examples for the reader to explore.

A wide range of institutions are engaged in this market. Deakin University in Australia, the University of California, Irvine, Western Governors' University, MIT (Massachusetts Institute of Technology, SUNY (State University of New York) and the University of Albany in the USA; Athabasca University, Ontario Tech University in Canada, and Tecnologico de Monterrey in Mexico. Public-private partnerships such as Coursera, Udacity, and edX, as well as university consortia like the OERu in New Zealand, the Micro-credentials Marketplace in Australia, the European MOOC Consortium (EMC), as well as eCampus Ontario and BCcampus in Canada have also entered the micro-credential field. Because of the competency focus of micro-credentials, many independent training organisations and certifying agencies have redirected their operations to engage in this rapidly growing market (COL, 2019; ICDE 2019; Matkin et al., 2020). 
In many institutions micro-credentials, whilst often credit bearing, can also be noncredit; and both may or may not apply towards a higher credential (Matkin et al., 2020). The U.S. and Canada have tended not to combine credit and non-credit credentials and/ or convert non-credit to credit applicability. A salient yet important issue that is likely to emerge pertains to accrediting oversight and the role of these agencies in micro-credentials. This is a rather gray area currently. For example, in the U.S., accrediting commissions historically have not held oversight over non-credit programming offered by Schools and Colleges. Indeed, this is a rather convoluted area, made problematic by the challenges associated with linking time requirements of academic credit to formal credentials. The specialised accrediting agencies that provide rigorous oversight, particularly of professional programmes (business, education, medicine, nursing, engineering, etc.) are positioned to play a more involved role in ensuring the quality of both credit and noncredit course offerings.

Conversely, Europe, New Zealand, and Australia are examples where national qualifications frameworks are driving the micro-credential development, and the focus is on academic credit bearing micro-credentials. In effect, these qualification frameworks are becoming practical roadmaps for non-credit bearing training and micro-credentials to be converted, certified and applicable towards credit-bearing formal credentials. Although this may occur, it may or may not be the major driver for non-credit to credit stackability. Many graduates, employees and employers are not interested in obtaining more formal credentials; rather they are focused on skill domain development and certification.

\section{Common micro-credential characteristics}

Micro-credentials generally attest to online course completions, but can also be applied in face-to-face or blended formats. There are also different authorities for validating credentials, including universities, colleges, agencies, professional associations, companies, and even peer reviewers. There are often multiple skill levels.(e.g., BeginningIntermediate-Advanced). They can be aligned or mapped to existing qualifications and/ or standards frameworks. Some micro-credential routes include information on funding opportunities and information on learner control of the qualification (e.g., portfolio, digital wallet, third party vendor, or repository).

\section{Types of micro-credentials}

There are different types of micro-credentials, all of which attest to or certify learning or skill attainments or competencies, based on some accepted form of assessment. Some certificates simply serve as proof of attendance and are not considered to be micro-credentials. These often take the form of badges, however some badges based on competencies can be micro-credentials when they certify learning and are linked to a reliable assessment. Other related terms include the EdX certification of Micro-Masters to label their micro-courses transferable to a defined master's degree. Nano-degree is a term used by Udacity to indicate an educational programme in computer science that covers the material (ICDE, 2019). Micro-credentials are often linked to MOOCs (Massive Open Online Courses) that can provide a wide range of credentials to learners (European MOOC Consortium, 2020). 


\section{The micro-credential landscape: affordances and barriers}

Universities and colleges entering the micro-credential market generally target the importance of unbundling these credentials from other services, and up-grading employee skills and competencies to help companies to remain competitive, adaptive, and current in the marketplace (Brown et al., 2021). For example, Athabasca University focuses on "micro-credentials" that are not for formal credit, but provide learners with "quick impact" training for immediate workplace applications. The University of California-Irvine reported on their ability to provide employers with self-verifying secure and unalterable permanent digital records of their graduates' abilities to perform valued skills. In addition, the graduates can own and control their credentials personally, rather than having to rely on the institution's transcript office (Matkin et al., 2020).

Similar justifications and affordances would likely be made by many universities worldwide that are engaged in micro-credentials or considering entry into the market. However, there are multiple approaches and loci of control for micro-credentials. Australia, New Zealand, UK, South Africa, and many other nations have national qualifications frameworks that drive skills and competency credentialing in their respective countries, though it appears these are designed to guide, rather than control micro-credential development.

The ICDE Working Group on Alternative Digital Credentials (2019) takes an even stronger stance, stating it is "imperative" that its member institutions engage in this arena. The report is a warning for ICDE member institutions, advising them to implement micro-credentials before other organizations "encroach on their traditional sphere of influence" (p. 12), stressing that micro-credentials will become essential to maintain competitiveness amongst universities. Students and employers are demanding digitally accessible systems to validate and document acquired skills and competencies via a separate transcript system. The report argues that open and distance education, and specifically OER, should be aligned with building micro-credentialing options for students and employers using online digital delivery.

\section{Affordances of micro-credentials}

Deakin University has provided an extensive summary of potential affordances of microcredentials that can provide organizations with a competitive advantage (DeakinCo, 2017). Among them are personalisation and recognition of those with specific skills, along with opening access to formal credentials. Short term mini-courses leading to micro-credentials provide employees and employers with flexibility and just-in-time training. Industries can scale-up their training, empowering employees to upskill, learning how to function in emerging new critical areas for an industry.

Various frameworks and working documents all reveal common affordances that may evolve from university engagement in the micro-credentials area (Australian Government, 2020; Brown et al., 2021; Burning Glass Technologies, 2017; Carnevale et al., 2020; Cirlan \& Loukkola, 2020; COL, 2019; Debiais-Sainto, 2020); European Union, 2018; FutureLearn, 2020; Kato et al., 2020; Matkin et al., 2020; MicroHE Consortium, 2019; NZQA, 2019; Oliver, 2019; and SUNY, 2020a, 2020b). Teachonline.ca (2021) has summarized specific stakeholder outcomes from micro-credentials. 


\section{Barriers to micro-credentials}

An obvious, yet often overlooked barrier to implementing micro-credentials is the lack of documented data demonstrating market need (Kato et al., 2020). Researchers must often infer indirectly from other related data sets to project market need particularly in a new target arena. Moreover, in the case of micro-credentials, there has not been sufficient time to integrate or develop comprehensive surveys to gather data based on any consistent definitions. These surveys will need to be validated and be designed using consistent definitions, if we are to gather useful metadata on specific micro-credentials.

There are many potential barriers to micro-credentials over and above inertia and the natural reluctance of institutions to change. Among them is the serious lack of senior leaders who understand micro-credentials or who are willing to act as change agents. This results in the lack of resources, both financial and human, allocated to institutional implementations. The lack of incentives for faculty in relation to promotion and tenure is another serious barrier. Where there is no reward tied to increased workload, cooperation is not to be expected. The view that micro-credentials are viewed as an "add-on" or "nice-to-do" rather than in strategic alignment with the institutional goals is a major impediment that impacts costing factors and human resource allocation (Cirlan \& Loukkola, 2020; COL, 2019; ICDE, 2019; Kato et al., 2020; Matkin et al., 2020; Pickard, 2018).

Learners want more options at lower costs to support their education and training for jobs. Employers want entry-level employees with better skills and capacity to learn, which in turn can give the company a competitive advantage in the marketplace. Finally, educational providers want to expand recruitment avenues to contribute to the modern workforce and remain competitive. The lesson for smart leaders is to integrate micro-credential initiatives with current institutional programs, make them easy to use with clear validation metrics, and, in this way, make micro-credentials a value-added benefit for all stakeholders. Table 1 provides a ready reference for university leaders.

\section{Micro-credentials and academic credit: the key factors}

Micro-credentials, when framed against the competency-based assessment models, remove a traditional variable nearly universally associated with the awarding of academic credit: TIME. Time in the classroom, time online, time on site doing research. This is one variable most could agree can be a measure of quality. However, this assessment has been challenged, with educators arguing that if the competencies in a targeted skill domain could be validated and assessed to a minimum performance level, then the time factor becomes less important (Custers \& Cate, 2018; Lowe, 2013; Snell \& Frank, 2010). Moreover, replacing the credit-hour with competencies-based assessment would be more equitable (Garn, 2019).

Notional time has been used by competency-based education advocates to address the concerns of credit-hour supporters and other critics. This is the average amount of time it takes for a student to achieve specific learning or skill competencies or outcomes. This time includes not only student-teacher contact time but also laboratory 
Table 1 A practical micro-credentials reference framework for university Leaders (McGreal et al., 2021)

\section{Definition}

(Draft European Commission)

A micro-credential is a recognised proof of the learning outcomes that a learner has acquired following a short learning experience. These learning outcomes have been assessed against transparent standards The proof is contained in a certified document that lists the name of the holder, the achieved learning outcomes, the assessment method, the awarding body and, where applicable, the qualifications framework level and the credits gained. Micro-credentials are owned by the learner, can be shared, are portable and may be combined into larger credentials or qualifications. They are underpinned by quality assurance following agreed standards. (p. 6) Debiais-Sainton (2020)

\section{Characteristics}

Focused on acquisition of skills and competencies Offered online, face-to-face, and/or blended delivery modalities

Short termed as compared to traditional degrees and certificates; for example, micro-credentials could be

3-days to 9 months

Created to verify credential as an evidence-based

validation

Awarded with academic credit or non-credit

Assessed through teer review (e.g., university, agency, professional body)

Consist of multiple skill levels (although not required), with competencies ranked by importance in each skill level and competency importance varying across levels

Aligned or mapped to existing qualifications and/or standards frameworks

Have a geographical footprint, where providers define their service region and critical skill areas are identified with employers

Characterized by autonomous transparency

Includes funding sources for development and assessment, resulting in cost to students

Identifies with an organizational entity to manage and provide oversight of micro-credentials

Stored in a digital repository (e.g., portfolio, digital wallet, third party vendor like Credly) for secure storage, verification, and stakeholder distribution. DebiaisSainton (2020), COL (2019), ICDE (2019), Kato et al. (2020), Matkin et al. (2020), Oliver (2019), Selvaratnam and Sankey (2020) and SUNY (2020b)

\section{Types of micro-Credentials**}

Certificate

Certification

MOOCs

Apprenticeships

Coding boot camps

Badges

Micro-Masters

Nano-degree

**These terms are defined in the Glossary

Cirlan and Loukkola (2020), Kurzweil (2020), OECD

(2021), ICDE (2019), Australian Government (2020),

DeakinCo (2017), COL (2019), Brown et al. (2021)

\section{Micro-Credential}

Information and Validation Elements

Title of the micro-credential

Country/Region

Awarding body

ISCED field of education and training

Date when the micro-credential was issued

Notional workload

Level of the learning experience

Learning outcomes

Form of participation in the learning activity

Type of assessment

Supervision and identity verification during assessment

Quality assurance of the credential

Prerequisites needed to enrol in the learning activity

Grade achieved

integration /stackability options

1 Duration of validity

2 Further information

Australian Government (2019, 2020), Cirlan and Loukkola (2020), Debiais-Sainton (2020), European Union (2018), Matkin et al. (2020) and New Zealand Qualifications Authority (2019)

time, research time, assignment completion time and assessment time. Whether credit or non-credit, the time factor whether notional or real time is an essential consideration with micro-credentials, particularly since assessments will be linked to specific competencies and ultimately to skill levels.

\section{Acceptance and applicability of micro-credentials}

Universities have traditionally been reluctant to accept credits from external sources. Transfer credits have generally been problematic. At first glance, it seems straightforward because the institution accepts transfer credit, but it becomes immediately apparent that transferability and applicability are not the same thing. The institution may 
accept credits but how these credits apply to any formal credential rests with the academic units as the locus of oversight and evaluation. In many instances, transfer credit ends up applying as elective credits but not to a student's major area of study or even minor area.

A major impediment in universities has been the reluctance of faculties and departments to recognise the value of credentials earned elsewhere, and they often control the decision-making. The fact is, as soon as the micro-credential discussion moves into the realm of academic credit in formal degrees, certificates, certifications, and other credentials, then university academic units and their faculties are front and centre and hence the credit equivalency conversion process is critical.

In general, universities have historically not focused extensively on establishing polices and processes for converting non-credit or non-formal educational activities to academic credit. The primary barriers were the issue of (1) time requirements (classroom and outside work) in non-credit activities not meeting the academic credit time minimums; and (2) the level and rigour of academic work (a valid quality issue) as not being commensurate with university credit requirements (McGreal et al., 2021).

What does this mean for micro-credential stackability or combining of formal/nonformal credentials? What it could mean is that if non-credit or non-formal activities can validate skills and competencies with flexible assessment of time requirements, the students may have opportunities to combine credit and non-credit micro-credentials towards higher formal qualifications. The amount of academic credit that might be given to stacked non-credit activities will be at the discretion of the institution awarding credit. In effect, this is no different from the evaluation of transfer credits currently in place at most institutions in North America.

Oliver (2019) noted the importance of clarifying the standards that are expected in micro-credentials, if they are to be accepted for credit in formal qualifications. Microcredentials for formal credit must include an assessment of learning achievement. The duration and effort required by the learner must be commensurate with the credit earned. Boud (2021) argues that micro-credentials must be for credit somewhere, otherwise they are not "credentials".

The European MOOC Consortium (2020) has developed the Common Micro-Credential Framework (CMF). It builds on existing systems, and the focus is on formal credential recognition. The CMF adopted a similar set of criteria as that used in the Bologna Process and the European Higher Education Area (EHEA). Micro-credentials within the CMF are defined in terms of student learning hours and educational level. The microcredential is based on the results of an included summative evaluation with a reliable method of identification verification at the point of assessment. The transcript must include a statement of the learning outcomes and study hours equivalency.

The framework examples of Australia, New Zealand, and Europe are not meant to suggest that all micro-credentials need to be in strict compliance with their respective frameworks. They simply serve as a core starting point for formal academic credit qualifications and the main drivers within the policy arena. Developing credit + nonformal education credentials is already occurring. The European approach to micro-credentials is both intriguing and ambitious - to build a common European qualification framework that builds upon many of the EU national qualifications frameworks in one major 
standard (European Commission, 2020). In many countries, it is a success just to get three universities to work together in the same region. Global university leaders will be watching Europe's development closely.

Pickard (2018) surveyed and researched MOOC-based micro-credentials. Their findings reflect an inconsistent and difficult landscape to navigate. She further argued that employers and students don't have time to navigate this minefield and so simplicity and consistency must be part of a MOOC provider's communications plan. Unsurprisingly, pricing and costs of micro-credentials are also all over the board, thus making any clear price comparisons almost impossible. It is possible that many micro-credentials could actually cost more for the student than academic credit-based programs.

In sum, universities and collegess have historically not focused extensively on establishing polices and processes for converting non-credit or non-formal educational activities to academic credit. The primary barriers were the issue of (1) time requirements (classroom and outside work) in non-credit activities not meeting the academic credit time minimums; and (2) the level and rigour of academic work (a valid quality issue) as not being commensurate with university credit requirements. It is too early to predict whether conversion of non-credit to credit bearing attestations will become a normative part of this micro-credential landscape in North American higher education. The history and experience of the challenges discussed above suggest the complexities of achieving widespread acceptance across systems without formal national qualification frameworks. This could mean that most institutions may opt to keep non-credit attestations separate from the formal micro-credentials. Can training and certification exist in both domains? They have for decades so the answer is clearly yes.

\section{Part II}

\section{The global micro-credential landscape: a snapshot}

The trend towards micro-credentials and skill-competency based training is growing globally. Skill and competency development aligned with workforce skills in cooperation with government and business employers is not entirely new. University continuing education units, professional agencies, private providers, and many large corporations (e. g. Microsoft, Hewlett Packard, HSBC, Suncor International, Royal Bank of Canada, Toyota) have been delivering skills-based training (Carnevale et al., 2020; Cirlan \& Loukkola, 2020; Kato et al., 2020; ICDE, 2019).

In the last decade, numerous universities and consortia worldwide have started to look seriously at this entire area (e.g. Western Governors University, Athabasca University and PowerED, the Open University and FutureLearn, Deakin University, RMIT (Royal Melbourne Institute of Technology), MIT, eCampusOntario, Udacity, Coursera, and edX). The traditional credentials continuum is being reconsidered, with an increased emphasis on the need to unbundle the content and the credential (Cirlan \& Loukkola, 2020; Fong et al., 2016). The onset of the global COVID-19 pandemic has been a catalyst for expansion of micro-credentials as unemployment and devastating economic crises during the pandemic have crippled many industries and sectors.

From a global perspective, Europe, the USA, New Zealand, and Australia have taken the lead in supporting micro-credentials, particularly amongst universities and collegess, with emerging developments occurring in Canada, Peru, Indonesia, Mexico, the United 
Arab Emirates, South Africa, Malaysia, and others. Moreover, existing private providers have geared up their business to address skills and competency markets. In addition to growth in these regions we are seeing increased interest and public commentary amongst many government, higher education, and corporate leaders internationally.

This section will provide a snapshot of global activity in micro-credentials. It is not intended to be a comprehensive study of the provision landscape, which is growing as this report is being written. A few government agencies and professional associations that are taking leadership roles moving micro-credentials on to national workforce agendas will also be discussed briefly. A few issues and questions will be presented in the discussion which relate primarily to the final section of this report that covers strategic perspective and options for university leaders going forward.

\section{North America: the U.S., Canada, and Mexico}

At times it is hard to fathom how the U.S. consistently maintains the strongest higher education systems in the world. The individual state focus creates many factors that take on a very different context than national systems like in most European countries, Australia, and most of the rest of the world. Many of the US characteristics are similar in Canadian provinces, and create both challenges and opportunities for micro-credentials. Nearly all colleges and universities in the U.S., since the Covid pivot, have some level of digital distance education activity and most have histories building public-private partnerships for workforce training and economic development.

Despite not having a national qualifications framework, U.S. and Canadian institutions are already offering a range of micro-credentials, and this can only expand. Athabasca University, eCampus Ontario, the State University System of New York, the University of Albany, University of California-Irvine, Georgetown University and hundreds of others are already getting into the mix. MIT Open Learning is leading a major global consortium called the Digital Credentials Consortium (https://digitalcredentials.mit.edu/).

The American Council of Education (www.acenet.edu/) has been exploring innovative ways to combine credit and non-credit/nonformal credentials into progressively formal credentials. In New York, a new initiative by the Workforce Development Institute's Future Skills Exchange Platform partnership with Credential Engine to provide job seekers across New York state with easy access to a growing body of national and industryrecognised certificates (WDI, 2020).

The U.S. market has been front and centre in micro-credentials given the visibility of edX, Udacity (2020) nanodegrees, Coursera specialisations, and MIT's MicroMasters. Additionally, many universities have adopted a competency-based approach such as Western Governors University, whilst others have expanded historically non-credit continuing education training and skills programs to prepare workforce personnel. The data on U.S. micro-credentials are extensive but the outsider must link directly with institutions because much of the activity is evolving from outreach and continuing education units that have historically been the driving force and locus of control for corporate training and professional development, particularly for credentials without formal academic credit.

In Canada, PowerED at Athabasca University, BCcampus and eCampus Ontario are leading the way in the micro-credentials arena. Alberta, $\mathrm{BC}$, Ontario, and the Maritime 
provinces all have formal qualifications frameworks. Unique initiatives such as the MyCreds.ca MesCertif.ca (2020) by the Association of Registrars and Universities and Colleges of Canada (ARUCC, 2020) are collaborating with Digitary and Split Mango, two private Vancouver-based companies, to provide students, providers, employers, and third parties with a readily accessible national bilingual credentials wallet. This is similar to the EuroPassport which is designed for European students to house their portfolio credentials in one document and so rendered readily accessible digitally for the student and for potential employers.

Given that online digital learning is pervasive across Canadian higher education, we should expect continued expansion and innovation by universities familiar with online learning, particularly those with a history of distance education like Athabasca Unversity, Thompson Rivers University, Memorial University, the University of Waterloo and many others, especially since the pivot to online learning resulting from the Covid epidemic. Public-private partnerships and engagement by select Canadian institutions in the Global Consortia for Micro-Credentials will continue to grow.

Mexico, though slowly exploring the micro-credentials trends will likely benefit from its previous North American collaborations with the U.S. and Canada. In particular, the Consortium for North American Higher Education Collaboration (CONAHEC) is a long-term initiative that remains vitally active today and so is a natural starting point for Mexican Higher Education to engage. Miriadax which is a partner in the European MOOC Consortium and Tecnologico de Monterrey provide distance learning expertise and experience to tap for workforce development and training across Mexico.

\section{Australia/New Zealand and Fiji}

In their ACODE Report entitled Survey of micro-credentialing practice in Australasian universities 2020, Selvaratnam and Sankey (2020) provide a good summary of the Australian higher education sector's current status with micro-credentials. Griffith University, Deakin Universityand RMIT lead the micro-credential market in Australia. However, there is significant activity by other universities and collegess across Australia, New Zealand and Fiji. Forty-seven (47) institutions were sent the survey with 34 responses $(72 \%)$. Seventeen (17) or 50\% have micro-credential policies with the remaining respondents indicating they we are reformulating policies.

Eleven (11) of the institutions have validation systems in place and nearly all inferred this would be the most complex feature of maintaining consistency and quality standards. These institutional systems are based on either the Australian Qualifications Framework (AQF) (Australian Government DoE, 2020) or the New Zealand Qualifications Framework (2020).

The data on types of credentials suggest short-courses are driving $82 \%$ of institutions and $50 \%$ are graduate level and about $30 \%$ at the undergraduate level. The short-course focus is typical of micro-credentials, but also a focus area of the Australian government to respond to the COVID-19 pandemic impact on unemployment and economic crisis. Most of these institutions presently focus on micro-credentials, with those associated with academic credit following guidelines traditionally outlined in the qualifications frameworks for Australia and New Zealand respectively. 
The combining or stackability of credentials, non-credit and credit, into traditional credentials is in various levels of development at different institutions. Again, these systems are progressively mature at Griffith, Deakin and RMIT in Australia and with Otago Polytechnic (home of OERu) in New Zealand. Overall, $88 \%$ of responding institutions have developed or are developing micro-credentials. New Zealand has formally instituted a funding mechanism for micro-credentials (Tertiary Education Commission, 2019).

A critical point in Australia and New Zealand is that micro-credentials are technically considered outside the formal qualifications frameworks, which have historically focused on credit-based qualifications. In 2019, an Expert Panel appointed by the Australian Government Department of Education (2019) conducted a major review of the Australian Qualifications Framework. In Sect. 4 of their final report, This panel recommended in their final report that micro-credentials and shorter-qualifications be addressed and integrated into the AQF's formal qualifications.

In essence, this is consistent with the approach being taken in New Zealand and Europe to align with existing national and European qualifications frameworks with a priority on stacking micro-credentials into formal qualifications. This is not suggesting that non-credit or non-formal training and competency validation won't be pursued by providers-quite the opposite-but it does mean for these to have maximum acceptance for stacking they will have to meet consistent credit qualifications criteria of formal credentials. And, as previously discussed, the number and applicability of academic credit will rest with the hosting organisation of the formal qualification.

\section{Open educational resource universitas (OERu)}

Based at Otago Polytechnic in New Zealand, OERu is one of the most innovative organizations in the world to combine online learning, OER and open systems across digital formats, with a diverse system of micro-credentialing. OERu offers a range of short-courses and seminars for non-credit that are stackable together into traditional credentials with partner universities. Students can also earn OERu certificates ranging in duration anywhere from two weeks to a sequencing of short-courses for a few months. OERu reflects a model that can be a replicable reset for institutions that are coming out of the global pandemic and are exploring their future strategic options of combining open resources and systems, digital online delivery, and the integration of micro-credentials.

In a recent survey by OERu (n.d.) of over 2000 enrolees taking OERu short courses, $39 \%$ indicated they were taking a course towards a formal academic credential; $46 \%$ indicated they would pursue an available micro-credential, and $34 \%$ indicated they were strongly considering this option. Clearly, these options for short-term qualifications are consistent with the growing interest and potential value of micro-credentials.

\section{Europe}

The most ambitious in scope and coverage driving the micro-credentials landscape is the European higher education area. A European approach to micro-credentials (European Commission, 2020 provides a comprehensive summary of major reports, next steps and building blocks for micro-credentials. These resources, in concert with numerous 
ERASMUS project documents and policy documents (MicroHE, EuroPass, EduOpen, and others), provide a rich resource for novices and experts designing their micro-credentials capacity.

As stated earlier in this report, Europe has taken an EU strategic approach to microcredentials building collaborative components around existing structures created during the Bologna Process and the European higher education area. Moreover, the European Qualifications Framework has provided another core structure from which to align these together (European Commission, 2020). Again, similar to Australia and New Zealand, these national/EU wide qualifications frameworks are not driving rigid requirements for micro-credentials; however, they are the foundations for formal credentials in which nonformal competency-based skills credentials will need to adhere for stackability and combinations towards formal credentials.

Possibly, the leading micro-credentials provider in Europe, the European MOOC consists of the main European MOOC platforms FutureLearn, FUN, MiriadaX, EduOpen and OpenupEd. These partners represent most of the MOOC development work in Europe in terms of learners and number of MOOCs, by offering together over 2000 MOOCs. Together, they represent a large network of 250 universities and collegess and companies working in a variety of European languages, including English, French, Spanish, and Italian. The creation of the European MOOC Consortium accelerates the collaboration amongst major European MOOC players, creating the power and the volume for a serious European MOOC movement. The Consortium has created the Common Micro-credential Framework (CMF) which aligns with the EHEA (EMC, 2020).

Dublin City University, in partnership with Future Learn has taken a European leadership role in micro-credentials. The Open University UK is also expanding in this arena, although it is beyond the scope of this report to predict the potential impact of Brexit on OU activity in Europe. FutureLearn, along with being a key member in the European MOOC Consortium, is also global, through its affiliation with the Open University.

\section{Asia, Africa, and Central-South America}

Although micro-credentials development has been slower in Asia, Africa, and parts of Latin and South America, some institutions are slowly starting to explore their potential. Many of these nations have qualifications frameworks in place. In addition, clearly targeted skills and competency development leading to employment is a powerful resource particularly in the developing world. Organisations like the Commonwealth of Learning $(\mathrm{COL})$, with a rich history in serving underserved disadvantaged populations, will be critical not only in Commonwealth countries but also in sharing practices and models for use in other developing regions. We are already seeing some activity in China, Malaysia, and Indonesia. In South America, Brazil's very early experience with mini-certificates for jobs training has not been sustained (D'Antoni et al., 2011).

\section{Consortia for micro-credentials}

We have already covered the OERu as well as the Digital Micro-credential Consortium (DMC) led by MIT's Open Learning unit. The European MOOC Consortium was discussed under European initiatives as well. Moreover, many professional associations take on consortia-like characteristics in advocacy and policy, and the 
micro-credentials arena is no exception. International organisations such as UNESCO, OECD, COL, ICDE, as well as many nationally-based associations, will play an increasing role in the development, policy formulation, and collaborative initiatives across the globe and in the different regions.

\section{Navigating the micro-credentials landscape}

Pickard (2018) reminded us that the micro-credential landscape is massive, confusing, unclear, and difficult to navigate for both students and employers. Moreover, pricing schedules are all over the board and yes, some micro-credentials could cost more than regular academic credit credentials if compared by per unit cost (Kato et al., 2020). Unbundling and re-combining will be messy because we are not completely certain what we are creating, only why we are creating this new credential base: to better enable students to get jobs and companies to thrive. It is an economic and workforce development initiative that uses university level education to enhance workforce mobility and student career trajectories.

Many, if not most, employers are still unaware and confused about the entire microcredential landscape (Cirlan \& Loukkola, 2020). Kato et al., (2020) reported that amongst OECD countries, employers generally still place a high value on traditional credentials-academic degrees and certificates.

\section{Complementary collaborative contexts}

In the U.S. and Canada, we see very little engagement by the national government in the micro-credentials arena directly. The autonomy of the states in the U.S. and the Canadian provinces provides a locus of control for higher education much different than in other countries where the national government and related ministries drive policy, accreditation, qualification standards and most importantly funding. There is also no equivalent European Commission in Canada, the U.S. and Mexico. This suggests that standardising micro-credentials globally may be difficult as well as trying to create a definitive taxonomy of micro-credentials. We currently have a reasonable sampling of different types of micro-credentials. Although difficult to implement, there is of course value in standardisation, provided providers retain the necessary flexibility to design, implement and assess effectively.

Micro-credentials are built around specific competencies where the student/ employee can demonstrate minimum levels of performance to be certified by a designated agency at a specific skill domain level. This suggests more than one roadmap to drive micro-credential development and implementation globally. We should see significant global differences in how micro-credential policies, certifications, minimum standards and stackability evolve but the goals will be similar: (1) to provide employees and employers a stronger talent pool; (2) to provide increased valuedadded capacity for companies and organizations as well as employees to thrive; and (3) to contribute to the overall workforce and economic development locally, regionally and perhaps nationally. In the end, the diversity of these paths will likely expand the validations of micro-credentials in meeting performance outcomes. 


\section{Lessons from practice}

A few general lessons have emerged from the valuable work done by existing microcredential providers globally that are reciprocally beneficial. First, micro-credentials are building off of existing qualifications frameworks or systems that have guided training and competency-based learning in the past. This does not mean all microcredentials will have identical criteria; however, it does suggest that stackability or combining of nonformal training and competency-based credentials into higher formal credit-bearing qualifications will be aligned and easier to realise in some universities and colleges systems (e.g., Europe, Australia, New Zealand, South Africa, etc.).

Secondly, assessment and precision are critical for ensuring credential and competency validation for issuance of credentials. Thirdly, a digitally secure and readily accessible repository for students and employers will exist outside of traditional university transcripts. This will ensure a portfolio home for employee/student credentials that, presented with traditional credentials, will provide employers with comprehensive metadata on potential hires. These data can be made available to employers digitally.

The ICDE (2019) report offered some basic recommendations to its members. Most of these consisted of sound advice, such as: set up a special unit for implementation, ensure top level support, pay attention to the research, allocate funding for microcredentials, develop an implementation plan, ensure uniform standards and policies, use a third-party vendor such as Credly to house and transcript the credentials, clarify clearly the criteria for issuance of the micro-credentials and the assessments and levels used in the process, and stay up to speed on evolving technologies.

\section{Summary}

The critical strategic reset question for university leaders is not how we engage in micro-credentials. The first question is should we engage at all; or to what degree? Does this trend align with the institutional mission, the programmatic strengths of academic programmes, and the increasing importance of good judgment in strategically allocating institutional resources? Indeed, like online learning and open education, one can effectively make the case for all institutions to be involved in workforce and economic development, however, at the end of the day the related question is how involved?

\section{Strategic reset: an opportunity disguised in the pandemic}

Returning to the perspective of 'strategic reset,' one option may be to explore the institutional integration of related key strategic initiatives. For example, micro-credetnials could be aligned with the pivot to online that many institutions are now undergoing; or combined with open educational resource implementations, as they have a common attribute-they can all be delivered and housed digitally. This is just one example. For some institutions, it will be a combination of different dimensions that may include community service, research, infrastructure upgrades, faculty incentives and resourcing, inter-institutional partnerships and more. The rationale for these is 
clear-digitalisation is driving the change and initiatives can mutually reinforce each other and institutional program delivery-diplomas, degrees, training, open textbooks and/or skill domain micro-credentials.

Definitions, language and context matter in the world of higher education, particularly related to micro-credentials and workforce development. Leaders and employers both will need to harness maximum clarity in communicating needs and solutions for leveraging the best micro-credentials for serving industry needs. Despite the documented evidence for the micro-credentials landscape to link to formal qualifications (academic credit, certificates, degrees), we must acknowledge and prepare now for the fact that many competencies and skill-based credentials will not line up with the typical requirements for formal credentials. Historically, non-credit offerings often did not impose the rigour for assessment and competency evaluation that would be commensurate with academic credit programs. Employers will want 'Just-in-Time' certified skill sets for specific needs-they won't care so much about formal credentials. Many micro-credentials will not be stackable without major overhauls, and hence they probably will remain short-term focused. Stackability sounds like good rhetoric, looks good on paper, but in practice is simply not practical in many cases. At the same time, it is acknowledged that the major micro-credential systems in Europe, Australia, and New Zealand are aligning noncredit offerings with the qualification frameworks that define credit bearing attestations.

Institutional leaders, attracted to micro-credentials because they think this might be your next 'cash cow' for a new revenue stream, perhaps should reconsider. The older historical models of offering noncredit training and certifications by universities were quick and effective and they could be offered at low cost to students.

Micro-credentials will face financial challenges if they are viewed as "nice-to-do" or an "extra. First, making micro-credentials a thriving new revenue stream for most institutions will be difficult. The strategy often used by institutions is to use non-credit short courses, certificates of completion, and 'Just-in-Time' training as a recruitment strategy enticing learners into the formal academic programmes. Why? The revenue stream for credit programmes is much higher and sustainable. Perhaps unknowingly, this has influenced the push towards micro-credentials linked to formal qualifications frameworks and the stackability language. We will need fresh new business models to leverage the micro-credential marketplace at most institutions.

A major cost factor of micro-credentials is their dependence on developing, administering and validating assessment instruments for the awarding of credentials (Kato et al., 2020). For example, a MOOC may be offered at low cost, but the provider still must provide upfront the developmental resources, which can be substantial. The reality is, no matter how we spin the rhetoric, micro-credentials will cost money, and resources will be a major factor for funders, providers, students and employers. Someone always has to pay.

Secondly, institutions may have to accept that micro-credentials are not viable as a major revenue stream. Moreover, to lower risk it is likely many institutions, not all, will explore consortia options similar to the Digital Credentials Consortia and the European MOOC Consortium discussed in this report. Institutions can benefit from sharing costs, 
lowering risk, and expanding offerings to the key stakeholder groups-students, employers, and partners.

Micro-credentials are not a panacea for resolving institutional challenges in the future. With sound planning and investment, integration with other key institutional programmes, and focus on providing what your institution does well, micro-credentials may, in fact, be a conduit to other forms of collaborations with the private sector partners, employers, and providers that expand opportunities for the institution and for students.

\section{Future research}

This paper provided an overview of the state of the art in micro-credentials that suggests possibilities for future research, not mentioned, but warranting research are the new smart technologies such as AI, and how they could be used to solve some of the identified challenges of micro-credentials. In addition, due to the wide array of terms and definitions presently being used for micro-credentials, an up-to-date taxonomy is needed. Blockchain hosting of credentials, controlled by the students is another technology that needs more research. How institutions make effective use of systems, both human and technological also warrant investigation.

\section{Appendix A}

\section{Selected global micro-credential providers North America}

Alberta University of the Arts

https://www.auarts.ca/continuing-education/micro-credentials

American Council of Education

https://www.acenet.edu/

Athabasca University PowerED

https://powered.athabascau.ca/

BCampus

https://bccampus.ca/projects/micro-credentials/

Class Central Massive List of MCs

https://www.classcentral.com/report/list-of-mooc-based-microcredentials/

Contact North/Contact Nord

https://contactnorth.ca/

eCampus Ontario

https://www.ecampusontario.ca/ecampusontario-leads-education-industry-collaborat ion-through-micro-certification/

eCampus Ontario Micro-Credentials Framework

https://micro.ecampusontario.ca

Coursera

https://www.coursera.org/

edX

https://www.edx.org/

Microsoft Certifications 
https://docs.microsoft.com/en-us/learn/certifications/certification-exams

MIT

https://www.edx.org/micromasters

Ryerson University School of Continuing Studies

https://coursecompare.ca/school/ryerson-university-chang-school/

University of Albany

https://www.albany.edu/micro-credentials

UC-Irvine Continuing Education

https://ce.uci.edu/

UC-Irvine Home

https://uci.edu/

University of Victoria Continuing Studies

https://continuingstudies.uvic.ca/

Western Governors University

https://www.wgu.edu/

Udacity

https://www.udacity.com/

\section{Australia/New Zealand}

Deakin University

https://www.deakin.edu.au/credentials

Griffith University

Approach to micro-credentials https://www.griffith.edu.au/apply/griffith-credentials

OERu

http://oeru.org

Types of micro-credentials available https://www.youracclaim.com/organizations/griff ith-university/badges

Fuller programs that can be earned through stacked micro-credentials:

https://app.secure.griffith.edu.au/credit-precedent/credit_result.php?filter $=3 \&$

micro $=1 \&$ Search $=$ Search + for + Micro-credentials

Professional learning site for organisations:

https://www.griffith.edu.au/engage/professional-learning/for-organisations

RMIT

https://www.rmit.edu.au/creds

OpenCreds

https://solutions.openlearning.com/opencreds

Open Education Resource universitas (OERu)

www.oeru.org

\section{Africa}

African Virtual University

www.avu.org

OER Africa.

https://www.oerafrica.org/

University of Cape Town. 
https://www.uct.ac.za/

\section{Asia}

Open University Malaysia

https://www.oum.edu.my/

Univerisitas Terbuka Indonesia Open University.

https://www.ut.ac.id/

\section{Latin/South America}

Miriadax

https://miriadax.net/home

Tecnologico de Monterrey (Mexico)

https://tec.mx/es

Universidad Peruana de

Ciencias Aplicadas.

https://www.upc.edu.pe/

\section{Europe}

A European approach to micro-credentials

https://ec.europa.eu/education/education-in-the-eu/european-education-area/aeuropean-approach-to-micro-credentials_en

European MOOC Consortium

https://emc.eadtu.eu/

Open University UK

http://www.open.ac.uk/

Delft University of Technology

https://www.tudelft.nl/

Dublin City University

https://www.dcu.ie/connected

EDUOpen.

https://learn.eduopen.org/

FutureLearn

https://www.futurelearn.com/

Glasgow University

https://www.gla.ac.uk/study/microcredentials/

iMOOC Universidad

Zaragoza and Universidad Politécnica de Madrid

http:/gridlab.upm.es/imooc/

MicroHE

https://microcredentials.eu/\#/

MicroBol

https://microcredentials.eu/about-2/microbol/\#/

Universidad Tecnológica de Graz

https://www.tugraz.at/en/home/

UNED Abierta. 
https://www.uned.es/universidad/inicio.html

\section{Micro-Credential Qualifications Frameworks and Policy Initiatives (Governments/Consortia/Associations) \\ Digital Credentials Consortium}

https://digitalcredentials.mit.edu/

Founding Members (Office @ MIT Open Learning Office)

Delft University of Technology (The Netherlands)

Georgia Tech (USA)

Harvard University (USA)

Hasso Plattner Institute, University of Potsdam (Germany)

Massachusetts Institute of Technology (USA)

McMaster University (Canada)

Tecnologico De Monterrey (Mexico)

TU Munich (Germany)

UC Berkeley (USA)

UC Irvine (USA).

University of Milano-Bicocca (Italy)

University of Toronto (Canada)

Alberta Qualifications Framework

https://open.alberta.ca/publications/alberta-credential-framework-at-a-glance

Australian Qualifications Framework (AQF)

https://www.aqf.edu.au/

Commonwealth of Learning (COL)

www.col.org

European Qualifications Framework http://www.ehea.info/Upload/TPG_A_QF_RO_

MK_1_EQF_Brochure.pdf

ICDE

www.icde.org

Maritime Degree Level Qualifications Framework http://www.mphec.ca/resources/

Maritime_Degree_Level_Qualifications_Framework.pdf

New Zealand Qualifications Authority (NZQA)

https://www.universitiesnz.ac.nz/quality-assurance/new-zealand-qualificationsframework-nzqf\#: :text=The\%20objective\%20of\%20the\%20NZQF,Zealand\%20Qualific ations\%20Authority\%20(NZQA).

OECD

https://www.oecd.org/

Ontario Qualifications Framework

http://www.tcu.gov.on.ca/pepg/programs/oqf/

Acknowledgements

Not applicable.

Authors' contributions

Both authors have substantially contributed to this work. The initial design was suggested and outlined by Rory McGreal along with a concept paper and reference list. Don Olcott Jr. conducted extensive research and drafted an initial draft that became the basis for this paper. The paper submitted represents a substantially modified version of this original 
report, amended and adapted by Rory McGreal and further edited and revised by Dr Olcott Jr. Both authors have approved the submitted version and are both personally accountable for their own contributions and are willing to ensure that questions related to the accuracy or integrity of any part of the work, even ones in which the author was not personally involved, are appropriately investigated, resolved, and the resolution documented in the literature.

\section{Funding}

Not Applicable.

\section{Availability of data and materials}

Not applicable.

\section{Declarations}

\section{Competing interests}

The authors declare that they have no competing interests.

\section{Author details}

${ }^{1}$ Athabasca University, Alberta, Canada. ${ }^{2}$ University of South Africa, Pretoria, South Africa.

Received: 10 September 2021 Accepted: 25 January 2022

Published online: 07 February 2022

\section{References}

American Council on Education (ACE). (2021). www.acenet.edu/.

Association of Registrars and Universities and Colleges of Canada (ARUCC).https://arucc.ca/en/.

Athabasca University. (n.d). https://powered.athabascau.ca/catalog?pagename=online-certificates.

Australian Government Department of Education. (2019). Expert Panel for the Review of the Australian Qualifications Framework. Review of the Australian Qualifications Framework: Final Report, Australian Department of Education, Canberra. https://www.voced.edu.au/content/ngv\%3A84730.

Australian Government Department of Education. (2020). Australian qualifications framework. Canberra, NSW. https:// www.aqf.edu.au/.

Bates, T. (2021). A review of online learning in 2020. Online Learning and Distance Education Resources. Contact North|Contact Nord. https://www.tonybates.ca/2020/12/16/a-review-ofonline-learning-in-2020/.

Boud, D. (2021, August 18). Teach Online In Using the Development of Micro-Credentials to Improve Diplomas and Degrees. https://contactnorth.zoom.us/rec/share/dPVsw_IwtyGD03u5QNuvoxOJfwXkmqVLAnaMiGMtwT2od1sP0QI9UI_ jFqB8CHMR.chngKL61j0gGokL6?startTime=1629327625000.

Brown, M., Giolla Mhichil, M.N., Beirne, E. \& Mac Lochlainn, C. (2021, in press). The global micro-credential landscape: Charting a new credential ecology for lifelong learning. Journal of Learning Development, 8(2). https://jl4d.org/index.php/ejl4d.

Burning Glass Technologies. (2017). The Narrow Ladder: The Value of Industry Certifications in the Job Market. Burning Glass Technologies, Boston. https://www.burning-glass.com/research-project/certifications/.

Carnevale, A. P., Fasules, M. L., \& Campbell, K. P. (2020). Workforce basics: The competencies employers want. Georgetown University Center on Education and Workforce, 1-72. https:/cew.georgetown.edu/cew-reports/competencies/.

CFIB (Canadian Federation of Independent Business). (2021, May). Business Barometer https://www.cfib-fcei.ca/sites/defau It/files/2021-05/business-barometer-Canada-2021-05.pdf.

Cirlan, E. \& Loukkola, T. (2020). European project MICROBOL: Microcredentials linked to the key Bologna commitments. European University Association (EUA), 1-63. https://eua.eu/downloads/publications/microbol\%20desk\%20res earch\%20report.pdf.

Commonwealth of Learning (COL). (2019). Designing and implementing micro-credentials: A guide for practitioners. http://oasis.col.org/handle/11599/3279.

Consortium for North American Higher Education Collaboration (CONAHEC). (2020) https://conahec.org/.

Contact Nord. (2020a). Ten facts you need to know about micro-credentials. https://teachonline.ca/tools-trends/tenfacts-you-need-know-about-micro-credentials.

Contact Nord. (2020b). Micro-credentials and the skills agenda: Twelve fundamental questions. 1-12. https://teachonline. $\mathrm{ca} /$ tools-trends/micro-credentials-and-skills-agenda.

Coursera. (2020). https://www.coursera.org/.

Custers, E., \& Care, O. (2018). The history of medical education in Europe and the United States, with respect to time and proficiency. Academic Medicine, 93(1), 549-554(546).

D'Antoni, S., McGreal, R., \& Mulder, F. (2011). Report on UNESCO/COL Workshop New York June 18-19 2011. https://auspace. athabascau.ca/bitstream/handle/2149/3084/Report_UNESCO_OER_Chairs_Network_Meeting\%2019072011.doc? sequence $=3$.

Deakin Co. (2017). What are micro-credentials and how can they benefit both businesses and employees? Deakin Co., 1-11. 24 October 2017. https://www.deakinco.com/media-centre/article/Benefits-of-micro-credentials-for-busin ess-and-employees\#: :text=Micro\%2Dcredentialing\%20offers\%20you\%20and,and\%20learning\%20on\%20the\% 20job.\&text=The\%20flexibility\%20and\%20incremental\%20nature,they\%20accumulate\%20in\%20their\%20role.

Debiais-Sainton, V. (2020). European approach to micro-credentials. EADTU Innovating Higher Education 2020 Bridging Event (I-HE2020). https://www2.slideshare.net/EADTU/ihe2020-european-approach-to-microcredentials.

Digital Credentials Consortium (DCC). (2020). https://digitalcredentials.mit.edu/.

Dublin City University (DCU). (2020). https://www.dcu.ie/connected/micro-credentials. 
edX. (2020). https://www.edx.org/micromasters.

Envoy Global. (2021, June 10). Covid-19's impact on the american economy: How has demand in sectors dependent on specialty skills changed due to Covid-19? New American Economy. https://research.newamericaneconomy.org/wp-conte nt/uploads/sites/2/2021/06/NAE-Envoy-Report-V2.pdf.

European Association of Distance Teaching Universities (EADTU). (2020). https://eadtu.eu/.

European MOOC Consortium (EMC). (n.d.). https://emc.eadtu.eu/.

European MOOC Consortium (EMC). (2020). EMC common microcredential framework. European MOOC Consortium, 1-13. https://emc.eadtu.eu/images/EMC_Common_Microcredential_Framework_.pdf.

European Commission. (2020). A European approach to micro-credentials. https://ec.europa.eu/education/education-inthe-eu/european-education-area/a-european-approach-to-micro-credentials_en.

European Union. (2018). The European qualification framework: Supporting learning, work, and cross-border mobility. Luxembourg City: European Union. http://www.ehea.info/Upload/TPG_A_QF_RO_MK_1_EQF_Brochure.pdf.

Fong, J., Janzow, P, \& Peck, K. (2016). Demographic shifts in educational demand and the rise of alternative credentials. Washington, D.C.: UPCEA-Pearson. https://upcea.edu/upceapearson-survey-demographic-shifts-in-educational-demandand-the-rise-of-alternative-credentials.

FutureLearn. (2020). How microcredentials work on FutureLearn, 1-4. https://futurelearn.zendesk.com/hc/en-us/articles/ 360036262474-How-microcredentials-work-on-FutureLearn.

Garn, M. (2019). Three decades and still counting (the wrong things): An analysis of three reports on the possibility and practicality of shifting our academic currency from credit hours to competencies. The Journal of Competency-Based Education. https://doi.org/10.1002/cbe2.1196

Griffith University. (2020). https://www.griffith.edu.au/apply/griffith-credentials

International Council for Open and Distance Education (ICDE). (2019). ICDE Report of the ICDE working group on The Present and Future of Alternative Digital Credentials (ADCS), 1-54. Oslo, Norway. https://static1.squarespace.com/static/5b99664675 f9eea7a3ecee82/t/5cc69fb771 c10b798657bf2f/1556520905468//CDE-ADC+report-January+2019+\%28002\%29.pdf.

Kato, S., Galan-Muros, V., \& Weko, T. (2020). The emergence of alternative credentials. OECD Education Working Paper No. 216. Organisation for Economic Co-operation and Development (OECD), 1-40. Paris: OECD. https://www.oecd.org/ publications/the-emergence-of-alternative-credentials-b741f39e-en.htm.

Kurzweil, M. (2020). The 74 interview: Researcher Martin Kurzweil on why more data is needed to prevent fraud and confusion in the non-degree credential landscape, The 74, 1-11. https://www.the74million.org/article/the-74-inter view-researcher-martin-kurzweil-on-why-more-data-is-needed-to-prevent-fraud-and-confusion-in-the-nondegree-credential-landscape/.

Lowe, W. (2013, December). It's only a matter of time: Clock hours vs. competency. https://www.ncbi.nlm.nih.gov/pmc/ articles/PMC3838309/.

Matkin, G., Charles, S., Alexander, J., Cartegena, H., Okhuysen, G., Hayes, G., Helbig, S., Knuff, D., Kurdahi, F., Minhas, J., Olivieri, V., Stephens, C., Kuan, Y., \& Jeantet, A. (2020). The University of California-Irvine report of the workgroup on alternative digital credentials (ADCs), 1-14.

Matkin, G. W. (2018). Alternative digital credentials: An imperative for higher education. Research \& Occasional Paper Series: CSHE.2.18. Center for Studies in Higher Education, 1-8. https://cshe.berkeley.edu/publications/alternativedigital-credentials-imperative-higher-education-gary-w-matkin.

McGreal, R., Mackintosh, W., \& Olcott Jr., D. (in press). Bridging the gap: Micro-credentials for development. UNESCO (WHEC 2021).

MicroHE Consortium. (2019). MicroHE. https://microcredentials.eu/.

MyCred.ca MesCretif. (2020). https://www.groningendeclaration.org/2020/12/11/arucc-launches-mycreds-mescertifcanadas-new-credential-wallet/.

New Zealand Qualifications Authority. (2019). Guidelines for applying for approval of a training scheme or a micro-credential. New Zealand Qualifications Authority, Wellington. https://www.nzqa.govt.nz/providers-partners/approval-accre ditation-and-registration/micro-credentials/quidelines-training-scheme-micro-credential/.

New Zealand Qualifications Frameworik. (n. d.). https://www.nzqa.govt.nz/assets/Studying-in-NZ/New-Zealand-Quali fication-Framework/requirements-nzqf.pdf

OECD. (2021, September 22). Quality and value of micro-credentials in higher education. OECD Publishing. https://www. oecd-ilibrary.org/education/quality-and-value-of-micro-credentials-inhigher-education_9c4ad26d-en.

Oliver, B. (2019). Making micro-credentials work for learners, employers and providers. https://dteach.deakin.edu.au/2019/ 08/02/microcredentials/.

Open Education Resource universitas (OERu). (n.d.). www.oeru.org.

Pickard, L. (2018). Analysis of 450 MOOC-Based Microcredentials Reveals Many Options But Little Consistency. https://www. classcentral.com/report/moocs-microcredentials-analysis-2018/.

RMIT. (2020). https://www.rmit.edu.au/creds.

Selvaratnam, R., \& Sankey, M. (2020). Survey of micro-credentialing practice in Australasian universities 2020, 1-4. https://stati c1.squarespace.com/static/5b99664675f9eea7a3ecee82/t/5f75ca9df9968a437d3ff886/1601555104097/ACODE_ MicroCreds_Whitepaper_2020.pdf.

Shah, D. (2021, July 28). Massive List of MOOC-based Microcredentials. The Report by Class Central. https://www.classcentr al.com/report/list-of-mooc-based-microcredentials/.

Snell, L. S., \& Frank, J. R. (2010). Competencies, the tea bag model, and the end of time. Medical Teacher, 32(8), 629-630. https://doi.org/10.3109/0142159X.2010.500707

State System of New York (SUNY). (2020a). Frequently asked questions. https://system.suny.edu/academic-affairs/micro credentials/faq

State System of New York (SUNY). (2020b). Microcredentials definition. https://system.suny.edu/academic-affairs/micro credentials/definitions/.

Tertiary Education Commission. (2019). Micro-credentials_Funding approval quidelines, Tertiary Education Commission, Wellington. https://www.tec.govt.nz/funding/funding-and-performance/investment/plan-guidance/micro-credentials/.

Tooley, M., \& Hood, J. (2021, January). Harnessing Microcredentials for Teacher Growth: A National Review of Early Best Practices. New America. https://files.eric.ed.gov/fulltext/ED612409.pdf. 
Udacity. (2020). https://www.udacity.com/.

Western Governors University (WGU). (2020). www.wgu.edu.

Workforce Development Institute (WDI). (2020). https://wdiny.org/Portals/0/WDI\%20Announces\%20New\%20Partners hip-\%20press\%20release\%20120720.pdf.

Zanville, H., \& Ton-Quinlivan, V. (2020). Covid-19 writes a prescription for change: Unbundling/rebundling learning. The evolllution, 1-4. 13 October 2020. https://evolllution.com/programming/credentials/covid-19-writes-a-prescriptionfor-change-unbundling-rebundling-learning/.

\section{Publisher's Note}

Springer Nature remains neutral with regard to jurisdictional claims in published maps and institutional affiliations.

Submit your manuscript to a SpringerOpen ${ }^{\circ}$ journal and benefit from:

- Convenient online submission

- Rigorous peer review

- Open access: articles freely available online

- High visibility within the field

- Retaining the copyright to your article

Submit your next manuscript at $\boldsymbol{\Delta}$ springeropen.com 